\title{
On Prisoners and Parenting: Preserving the Tie That Binds
}

Individuals sentenced to terms in prison must leave behind many of the familiar relationships of outside society; yet incarceration cannot dissolve all of an offender's ties and responsibilities. Many persons now serving time in this country's jails and prisons left children behind when they began to serve their sentences. ${ }^{1}$ For those parents in prison who were the sole or primary caregivers for their children before incarceration, the beginning of a term of imprisonment upsets existing child-care arrangements and requires that new arrangements be made. ${ }^{2}$

This Note examines the psychological problems of children caused by the incarceration of a child's primary caregiver. Part I reviews current laws and practices concerning the placement of children of incarcerated parents. Because parents and children are often separated under current practice, Part I also examines the psychological impact of separation on children. Part II demonstrates that current methods of

1. Currently there are approximately 426,000 men and 24,000 women incarcerated in the United States. See R. Deming, Women: The New Criminals 149 (1977). An estimated 70 to $80 \%$ of the women in penal custody have given birth to one or more children. See Polier, The Rights of Children, in ProceEdings of THE UNIVERSITY OF IWIsconsin CoNFERENCE ON ChILd Advocacy 34, 35-36 (J. Westman ed. 1976); Singer, Women and the Correctional Process, 11 Am. Crm. L. REv. 295, 302 (1973); Junior League of the City of New York, Prison Nursery Study: A Summary Report of Findings 1 (August 1974) (on file with Yale Law Journal). This general estimate is consistent with findings from a number of studies of different samples of incarcerated women. In a 1967 Pennsylvania study, 80\% of the women prisoners had children. Velimesis, Criminal Justice for the Female Offender, 63 AM. A.U. Women J. 13, 14 (1969). A study of a sample of women incarcerated in the United States reported that $73 \%$ of the women studied had borne children and that the average number of children born was 2.48. R. Gurck \& V. Neto, National Study of Women's Correctional Programs xviii (1977). This study noted, however, that only $56.3 \%$ of the women surveyed had dependent children actually living with them immediately prior to incarceration. Id. at 116. When the mother of a child had previously been incarcerated, the likelihood that her child had not been in her care immediately prior to the most recent incarceration was almost doubled. Id. at 119. The study did not indicate whether this difference resulted from court action or from voluntary relinquishment.

Unfortunately, comparable statistics are not available for male prisoners, although several lawsuits contesting the termination of their parental rights have been initiated by incarcerated fathers. See, e.g., In re Jones, 34 Ill. App. 3d 603, 340 N.E.2d 269 (1975). Although more female than male prisoners are currently affected by the issues discussed in this Note, the issues are equally applicable to men who are the sole or primary caregivers for their children at the time of incarceration.

2. Women prisoners, especially those from large urban areas, are especially likely to be the sole caregivers for their children. Trecker, The Children, in IN Prison 88, 90 (J. Trupin ed. 1975). In 1972 the female prison population of New York City Correctional Institution for Women at Rikers Island included 106 mothers, of whom 104 were heads of household. Junior League of the City of New York, supra note 1, at 5. 
providing temporary care for children of incarcerated parents take inadequate account of the child's need for continuity of care and thus fail to fulfill the stated intention of child welfare statutes to provide care that is in the best interests of the child. Finally, Part III proposes a system of caring for the children of incarcerated parents that should prove less harmful to the psychological development of the children, including provisions for allowing infants to remain under the care of their parent while the parent is in prison. These proposals are designed to aid states in drafting legislation that will better protect the interests of the children of incarcerated adults.

\section{Defining the Premises: Custody of Children of Prisoner Parents}

\section{A. Separation of Parent and Child: Current Law and Practice}

At present, a child is routinely separated from her parent when the parent is imprisoned..$^{3}$ Some states retain statutes that permit the permanent termination of parental rights of a parent in prison, based either on the parent's conviction ${ }^{4}$ or on vague standards of parental unfitness. ${ }^{5}$ Other states have statutory provisions that deprive felons

3. See generally Comment, The Prisoner-Mother and Her Child, 1 CAP. U.L. REv. 127, $129,138-39$ (1972). Three states provide by statute that very young children may remain in prison with their mother for limited periods of time. Cal. PENaL Code $\$ 3401$ (West 1970); FLA. STAT. $\$ 944.24(2)$ (1974) (applies only to children born in prison); N.Y. CoRREc. LAw $\$ 611$ (McKinney 1968). Statutes in each of these states provide that the infant will normally be removed from the penal institution by the age of 18 months. Although such provisions show concern for the welfare of children, they may nonetheless cause significant distress to a child by requiring separation from the mother during a critical period in development. See pp. 1414-15 \& notes 23-30 infra.

4. States that permit the parent's criminality to be used as an express ground for the termination of parental rights require that certain conditions be met before the parental rights can be terminated. In California the parental rights of persons convicted of a felony may be terminated when the nature of the crime is such as to "prove the unfitness of such parent or parents to have the future custody and control of the child." Cal. Civ. Code $\S 232.1(4)$ (West Supp. 1978). Similarly, in Oregon if a parent is imprisoned in a state or federal prison fór a term of not less than three years and has actually served three years, the court, after a hearing, can place the child for adoption without the parent's consent if the court finds that the welfare of the child will best be promoted through adoption. OR. REv. STAT. $\$ 109.322$ (1977).

5. See C. Foote, R. Levy \& F. Sander, Cases and Materiats on Family Law 210 (1976). For example, the Arkansas statute dealing with adoption includes in the definition of "dependent-neglected juvenile" any juvenile who is "under such improper guardianship or control, as to endanger the morals, health, or welfare of himself or others." ARK. STAT. ANN. $\S 45.403(4)$ (c) (Supp. 1975). Such vague statutory standards of parental unfitness may permit admission of the parent's conviction as evidence of unfitness to care for a child. In Smith v. Andrews, 54 Ill. App. 2d 51, 62-63, 203 N.E.2d 160, 166 (1964), cert. denied, 382 U.S. 1029 (1966), an Illinois court held that a male defendant who had been convicted of robbery and rape and who had allegedly spoken of plans to rob a bank and " 'get the judge, jury and the cops" " when released was depraved within the meaning of a statute permitting adoption without the consent of a parent who is unfit by reason of depravity. 
of their civil rights and thus eliminate the requirement of a convicted felon's consent to the adoption of her child. ${ }^{\circ}$ Recently, however, states have become increasingly reluctant to terminate parental rights upon conviction of the parent, and in several states laws that permitted the termination of parental rights on vague grounds have been repealed. ${ }^{7}$

The increasing retention of parental rights by parents during a period of incarceration poses new problems for legislatures and social welfare agencies. If a parent is to regain custody of a child after release from prison, the child cannot be placed in a new family on a permanent basis; some arrangement must be made for temporary care. Many parents are able to make satisfactory child-care arrangements without an active role by the state, often by leaving the child with relatives. ${ }^{8} \mathrm{~A}$ minority of children, however, are taken into state custody, either because no relative is available to provide child-care or because welfare agency personnel conclude that the interests of the child require care

Id. (quoting testimony of plaintiff). See Tiernan v. Stewart, 33 Ill. App. $3 d$ 545, 549, 338 N.E.2d 153, 156 (1975) (father found depraved within purview of adoption statute on basis of course of conduct including past convictions showing unwillingness to conform to accepted morality). But see In re Adoption of Kleba, 37 Ill. App. 3d 163, 166, 345 N.E.2d 714, 717 (1976) (past convictions, although relevant, may not be exclusive basis for finding of depravity). Many of these vague neglect statutes are currently undergoing revision. For a recent summary, see Katz, Howe \& McGrath, Child Neglect Laws in America, 9 FAM. L.Q. 1 (1975).

6. Project, The Collateral Consequences of a Criminal Conviction, 23 VAND. L. RLv. 929, 1076-77 (1970); see, e.g., N.Y. Civ. RIGHTs LAw \$ 79(1) (McKinney 1976) ("A sentence of imprisonment in a state correctional institution ... suspends . . all the civil rights [of] ... the person sentenced.") Despite a 1973 amendment to this statute restoring a prisoner's right to sue in court, a New York court found that an imprisoned parent's consent to the adoption of her child was not necessary. In re Anonymous, 79 Misc. 2d 280, 359 N.Y.S.2d 738 (Surr. Ct. 1974), modified on other grounds sub nom. In re Adoption of Robert A.M., 81 Misc. 2d 282, 366 N.Y.S.2d 343 (Surr. Ct. 1975). Indeed, once a parent has been convicted of a felony and imprisoned, the fact that she is put on parole and is therefore physically free to fulfill parental obligations does not terminate her sentence or restore her civil rights. Thus her consent to the adoption of her child is still not required. See In re Adoption of O'Daniel, 128 N.Y.S.2d 351 (Surr. Ct. 1953).

7. For examples of neglect or unfitness statutes that have recently been amended to require a showing of specific harm to the child before parental rights can be terminated, see Colo. Rev. Stat. \$19-2-101(b) (1973); IOWA Code ANN. \$ 600 A.8 (West Supp. 1977).

8. Most of the children of prisoners are currently left in the care of relatives. $R$. Gick \& V. NEro, supra note 1, at 119; Junior League of the City of New York, supra note 1, at 8. For cases approving of this practice, see Diernfeld v. People, 137 Colo. 238, 323 P.2d 628 (1958) (parental rights of mother serving second prison term for forgery could not bc terminated because child entrusted to care of child's grandmother); Welfare Comm'r $v$. Anonymous, 33 Conn. Supp. 100, 364 A.2d 250 (Super. Ct. 1976) (parent could avoid state intervention by arranging alternative care even though she was about to enter prison); In re Valdez, $29 \mathrm{Utah} 2 \mathrm{~d} 63,504 \mathrm{P} .2 \mathrm{~d} 1372$ (1973) (children could not be found dependent when father who had been incarcerated for murder of mother arranged for relatives to care for children). In cases such as these, state officials usually take no interest in the children beyond granting aid to dependent children of families in need. Junior I.eague of the City of New York, supra note 1, at 1. 
by the state. ${ }^{9}$ Like other children in state custody, such children may be placed either in a state institution or in a foster home under state supervision. ${ }^{10}$ In such cases of state custody, child welfare personnel often retain the right to decide when the parent is fit to regain custody of the child after the parent is released from prison. ${ }^{11}$

Thus the most common current practices involve separation of the parent and child when a parent who is the child's primary caregiver is imprisoned, and relocation of the child on at least a temporary basis. This practice aggravates the disruption to the family caused by the incarceration of a parent and may cause serious emotional harm to the child. ${ }^{12}$

\section{B. Maintenance of the Parent-Child Bond: The Psychological Premise}

Research in developmental psychology, as well as psychoanalytic theory, demonstrates that one of the most critical factors in the development of an emotionally healthy child is the formation of a strong and

9. Neglect statutes are usually written sufficiently broadly so as to allow state intervention in any situation in which parental habits or values are thought to be adverse to the inculcation of proper moral values. Mnookin, Foster Care-In Whose Best Interest?, 43 HARv. Eouc. REv. 599, 604 (1973). If this state intervention is challenged, it may be forbidden by the courts, see note 8 supra (citing cases), but few decisions to place children in foster care are actually appealed. Mnookin, supra at 609. For cases in which courts have ordered children placed in state custody during a parent's incarceration, see State v. Grady, 231 Or. 65, 371 P.2d 68 (1972); In re Sego, 7 Wash. App. 457, 419 P.2d 881 (1972). Grady, much criticized by subsequent cases, held that, although the mother's conviction for forgery did not justify a complete severance of her parental rights, her behavior and subsequent incarceration were sufficient to warrant an order committing the child to the temporary custody of the Welfare Commission. In Sego the court held that the child's legal status as a dependent child, and hence the state's right to take the child into custody, was not affected by the availability of relatives willing to provide care.

10. Unfortunately, few statistics are available showing where children of prisoners are placed. See Polier, supra note 1 , at 35-36. In one study of 727 children under five years of age whose mothers were incarcerated, 506 (approximately 70\%) were in the care of relatives, 104 (approximately 14\%) had been placed in foster homes, 33 (approximately 5\%) had been placed in institutions, and another 38 (approximately $5 \%$ ) had been placed in adoptive homes. Junior League of the City of New York, supra note 1, at 7-8. Of a sample of 101 children born in 1973 while their mothers were actually in American prisons, 62 (approximately 69\%) were cared for by relatives, 27 (approximately 2\%\%) were placed in foster care, one was placed in an institution, three (approximately three percent) were placed for adoption, and four (approximately four percent) were kept in the prison facility with their mothers. Id. at 8 .

11. This is generally true of all children placed in state custody. Campbell, The Neglected Child: His Family and His Family's Treatment Under Massachusetts Law and Practice and Their Rights Under the Due Process Clause, 4 Suffolk U.L. REv. 631, 647 (1970). In State v. Grady, 231 Or. 65, 371 P.2d 68 (1972), the court directed that the child be placed in temporary custody for the period of the mother's confinement and for a reasonable period thereafter until the defendant had an opportunity to establish herself and to demonstrate to the court her stability, reliability, and competence to care for her baby.

12. See pp. $1413-17$ infra. 


\section{enduring attachment bond to at least one caregiver during infancy ${ }^{13}$ This bond, normally formed as a result of the day-to-day interaction between infant and parent, ${ }^{14}$ is the emotional tie that enables the child}

13. See generally J. Bowlby, Atrachment and Loss: AtTacharent 177-358 (1969) thereinafter cited as AtTACHMENT]; J. Bowley, Child CARE ANd the Growth of Love (1953) [hereinafter cited as Child Care]; J. Goldstein, A. Freud \& A. Solnit, Beyond the Best Interests of the Child 17-20 (1973); R. Pation \& L. Gardner, Growth Fallure in Maternal Deprivation $38-40$ (1963); Ainsworth, The Development of Infant-Mother Attachment, in 3 Review of Child DevelopMent Research 1 (1973).

The importance of the parent-child bond was first formally recognized in psychoanalytic theory. See Hartmann, Kris \& Loewenstein, Comments on the Formation of Psychic Structure, 2 Psychoanalytic Study of The Child 11 (1946); Klein, Some Theoretical Conclusions Regarding the Emotional Life of the Infant, in Develormenrs in Psycuoanalysis 198 (1952). In 1935 Freud wrote that the mother's importance to the child is "unique, without parallel, laid down unaiterably for a whole lifetime, as the first and strongest love-object and as the prototype of all later love relations ...." S. FreUd, AN OUTLiNE OF Psychoanalysis 90 (1949). In 1958 Bowlby integrated this psychoanalytic notion with work in other disciplines to produce a theory of attachment based on the nature and origins of a child's ties to her mother. Bowlby, The Nature of the Child's Tie to His Mother, 39 INT'L J. Psychoanalysis 350 (1958). In the past 15 years Bowlby's theoretical work on attachment has been supplemented by an increasing amount of empirical research on the parent-child bond and its importance for later development. See generally MI. RutTer, The Quatities of Mothering (1974); Ainsworth, supra. Although much of this research focused on qualifying the sweeping conclusions of Bowlby's early writing, there does exist general agreement among child psychologists that the lack of a solid and enduring bond between a child and a primary caretaker will cause psychological harm. J. Kagan \& E. Havemann, Psychology 533-37 (1972); P. Mussen \& M. Rosenzweig, PsyCHOLOGY 318 (1973); Ainsworth, supra at 3. What controversy exists in the literature centers around whether the tendency of an infant to become attached to her caretaker is the result of innate drives or of a learned awareness by the infant that the caretaker will satisfy her needs. See J. KaGAN \& E. HavenanN, supra at 533-37; Corter, Infant Altachments, in New Perspectives in Child Development 164, 174-79 (B. Foss ed. 1974). All theories of attachment suggest, however, that the infant is not born with a ready-made attachment to a particular parent; rather, the attachment must develop over time. Ainsworth, supra at 1 . It is also clear that the person with whom an attachment bond is formed need not be the biological parent; it can be any person with whom the child has substantial and continual interaction. Id. at 28.

One other area of controversy relates to the effects of separating children from parents in later childhood. In part, this uncertainty is a product of the difficulty of conducting research on such matters. Because separation of older children from parents usually follows a period of considerable trauma within the family, it is often impossible later to isolate the specific origins of harm to the child. Nevertheless, there is considerable agreement that even older children are harmed by the subsequent lack of continuity in parenting that often follows separation from a natural parent. See pp. 1416, 1419.21 infra. The need of the older child for continuity of care has been recognized by courts and in legal writing. E.g., Apgar v. Beauter, 75 Misc. 2d 439, 440, 347 N.Y.S.2d 872, 875 (Sup. Ct. 1973) ("It is a general and well-established principle . . . that the welfare of a child is best served by remaining with its natural parent."); J. Goldstern, A. Freud \& A. SolNit, supra at 20 (interference with parental ties is emotionally painful to child); Wald, State Iniervention on Behalf of "Neglected" Children: A Search for Realistic Standards, 27 STAN. L. REv. 985, 994 (1975) (removing child from family may cause serious psychological damage).

14. Ainsworth, supra note 13 , at 2 . Although there is a tendency to speak of a baby as " "having become attached," attachment is actually a process composed of at least four distinct phases. Id. at 10. During the first phase, roughly the first two or three months of life, the infant does not overtly discriminate between caretakers, although she does have the sensory capacity to do so. $I d$. at 11 . During the second phase, the infant clearly discriminates between familiar figures (her mother and possibly one or two others) and those 
to internalize the parent's wishes and to learn to relate effectively to other people. ${ }^{15}$ Once such a bond is formed, it is specific to the particular adult or adults with whom the child has frequent interaction. ${ }^{16} \mathrm{Al}$ though it is possible for the child to form an attachment bond to more than one person with whom she has frequent contact, the number of such bonds that a child can form is limited. ${ }^{17}$ Preventing the formation of this bond or separating the child from a caregiver once the bond has been formed can seriously disrupt the child's emotional development. ${ }^{18}$

In a normal parent-child relationship, an attachment bond is formed when the child is between the ages of six months and two years. ${ }^{19}$ If no such bond is formed during this period, either because institutionalization does not provide a primary caregiver figure ${ }^{20}$ or because

who are relatively unfamiliar. "The end of this phase comes with the emergence of more active proximity-seeking and contact-mantaining behaviors, perhaps as early as six months of age, perhaps later according to rearing conditions and sensorimotor development ...." Id. at 11-12. During the third phase there is a striking increase in the infant's Initiative in promoting proximity and contact. Her signals are no Ionger expressive or reactive; they are often intended to evoke a response from the individual to whom the child has become attached. The median age for attaining this phase is about seven months, and this is the stage at which the infant is usually first described as attached. $I d$, at 12 . The last stage, which is thought to begin around the age of three and about which considerably less is known, has been called the phase of goal-directed partnership. ATtachMENT, supra note 13, at 267.68; Ainsworth, supra note 13, at 12. In this stage the baby begins to understand the goals of her parent and can adapt to conform to them. Id. at 12-13.

15. The wish to maintain parental love seems to be a most important stimulus for the infant to acquire control over her behavior, to delay responses, and to plan and anticipate actions. Goldfarb, Emotional and Intellectual Consequences of Psychologic Deprivation in Infancy: A Revaluation, in Psychopathology of Childhood 105, 116 (1955).

16. E. Hetherington \& R. Parke, Child Psychology 319 (1975).

17. Ainsworth, supra note 13 , at 1 . The attachment bond is manifested by common behavior such as looking, smiling, and contact-seeking, which the child uses to initiate and maintain interaction with familiar caregivers. Ainsworth, Patterns of Attachment Behavior Shown by an Infant in Interaction With His Mother, 10 MERRILL-PALMER Q. $51-58$ (1964). Once the infant has shown these signs of attachment, she will show considerable distress when separated from her accustomed caregiver, Ainsworth, supra note 13, at 65, and will protest loudly when others attempt to pick her up, rock her, or feed her, P. MUSSEN, J. Conger \& J. Kagan, Child Development and Personality 204 (1974).

18. See pp. 1413-15 infra \& note 13 supra (citing sources).

19. See note 14 supra. Studies of diverse cultures in such countries as Guatemala, Scotland, and Uganda have confirmed the findings of American research that attachment to the mother generally emerges clearly by six months and becomes more intense during the next three or four months. See J. KAGAN \& E. HAvemanN, supra note 13, at 204; P. Mussen \& M. Rosenzweig, supra note 13, at 316; Ainsworth, supra note 13, at 12-13. Most discussions of attachment theory agree that the infant's attachment to her primary caregiver begins to form after the first few months of life and is the strongest influence on the baby's development during at least the first 18 months. See J. Kagan \& E. Havemann, supra note 13, at 534; Ainsworth, supra note 13, at 40-42, 68 .

20. Much of the early research on the effects of institutionalization during infancy did not differentiate between the harmful effects resulting from the lack of perceptual stimulation that often occurs in institutional environments and the harmful effects resulting from lack of attachment to a parent figure. For summaries of this early research, see Child Care, supra note 13, at 11-71; Casler, Maternal Deprivation: A Critical Review of the Literature, 26 Monographs of THE Society for Research IN Child Development 
transfers from one home to another provide only shifting caregivers, the child may experience socialization problems. ${ }^{21}$ The child may be unable later in life to internalize acceptable norms of behavior and may experience difficulty establishing close interpersonal relationships. ${ }^{22}$

If an attachment bond is formed, breaking the bond by separating parent and child during this critical period of infancy is likely to cause distress to the child. ${ }^{23}$ The severity and long-term effects of this distress will depend both on the length of the separation and on the child's opportunity to replace the lost relationship with a new one. The adverse long-term effects of a parent-child separation may be minimized if the child is reunited with the parent within a fairly short time. ${ }^{24}$ Or,

(1961); Yarrow, Maternal Deprivation: Toward an Empirical and Conceptual Re.evaluation, 58 Psychological Bull. 459 (1961). Today it is believed that the stimulus deprivation inherent in many institutional environments may be responsible for the incidence of gross motor and intellectual retardation observed in these early studies. See M. RuTtER, supra note 13 , at 85,118 . This Note is concerned with the effect of raising an infant with a series of changing caretakers rather than with the effects of such severe conditions of deprivation. Still, there is general consensus that placements in institutions that do not provide children with attachment figures are extremely detrimental. Wald, supra note 13 , at 994; see P. Mussen \& M. Rosenzweig, supra note 13, at 318; Ainsworth, supra note 13, at 53. More severe and less reversible effects seem to be limited to cmotional and behavioral rather than motor or intellectual disturbances. M. RUTTER, supra note 13, at 86; Ainsworth, supra note 13 , at 53-54.

21. Children who do not form an attachment bond to any caretakers during infancy have a particularly poor outcome. M. RuTTER, supra note 13 , at 71 . They tend not to have a normal capacity for inhibitions, and they tend to be hyperactive, restless, and unable to concentrate. Goldfarb, supra note 15 , at 108-09.

22. Several studies have shown that children who do not form a stable bond with a caretaker during infancy are likely to develop a pattern of psychopathic behavior and an inability to relate to other people. This syndrome has been called "affectionless psychopathy," Bowlby, Forty-Four Juvenile Thieves: Their Characters and Home-Life, 25 INT'L J. Psycho-Analysis 107, 121-25 (1914), and is thought to be the one outcome of scparation that is a crucial function of the age of the child. M. RuTrER, supra note 13, at 72. Characteristics of the "affectionless psychopath" include a lack of guilt, an inability to follow rules, and an inability to form lasting relationships. $I d$. at 103 . The poor development of children who fail to form attachment bonds in infancy has also been noted in Goldfarb, supra note 15, at 109-10. Goldfarb found that children raised in institutions during infancy later craved affection and were unable to form lasting relationships. $I d$.

A study that investigated possible reasons for differences between stable and maladjusted children in long-term care found that the maladjusted children were more likely to have been separated from their mothers before a bond had been formed. The outstanding characteristic of these children was an inability to form relationships with adults or children. Pringle \& Bossio, Early Prolonged Separation and Emotional Maladjustment, 1 J. Child Psychology \& Psychiatry \& Allied Disciplines 37 (1960).

23. Experts on adoption recognize that there is a real danger of trauma if infants are taken from a parental figure to whom an attachment has formed. Foster, Adoption and Child Custody: Best Interests of the Child?, 22 Buffalo L. REv. 1, 13 (1972) (citing authorities). For a review of the many studies showing adverse effects of separating children from parents after an attachment bond has been formed but before the period of infancy has passed, see Xarrow, Separation from Parents During Early Childhood, in I REvIEw of Child Development Research 89 (1964).

24. Ainsworth, supra note 13, at 66 . The first reaction of an infant to separation from a caregiver indicates her distress. She cries, calls, and looks up at every sight or sound that 
the danger of serious damage to the child may be averted if the child is placed in a new environment that permits the establishment of a stable new relationship. ${ }^{25}$ But a child separated from her parent and placed in an institution or otherwise subjected to a series of changing caregivers is unlikely to develop a replacement bond. Such a child may go through successive stages of active protest, temporary withdrawal from human interaction, and, finally, complete detachment from affective relationships. ${ }^{20}$ The child may then follow a course of emotional development similar to that of infants who never formed an attachment bond. ${ }^{27}$

Although little is known about whether the ill effects of parent-child separation can be reversed later in childhood, ${ }^{28}$ it appears that reversal becomes more difficult after the child is no longer an infant. ${ }^{29}$ When the effects are not reversed, the child may develop what is known as a psychopathic personality-a tendency to break the law because normal guilt reactions for inappropriate behavior are lacking: ${ }^{30}$

might signal the return of the mother. She tends to reject comfort from others. Although she may cling to a nurse, as though in desperation, she will avoid looking at the nurse's face, $I d$, at $66-67$. This initial distress reaction appears to be fairly universal. In a study of 100 infants who were moved from a foster home to an adoptive home it was found that $58 \%$ of the infants transferred at the age of six months and $100 \%$ of the infants transferred at eight months showed marked disturbance. Ainsworth, supra note 13, at 36-37. But though a child who is reunited with her mother within a few days may show some delay in attachment behavior upon reunion with the mother, adverse long-term effects are less common. Id. at 66. See generally C. Heinicke \& I. Westheimer, Brief SeParations (1965).

25. Studies have also shown that a child separated from a parent and placed in an adoptive home early in infancy may adjust well to the new placement. E.g., Gardner, Hawkes \&: Burchinal, Noncontinuous Mothering in Infancy and Development in Later Childhood, 32 Chicd Dev. 225 (1961). Once an infant has become attached to one caregiver, however, it may be difficult for her to become attached to a new one. Ainsworth, supra note 13 , at 41 . The development of attachment to a new caregiver becomes increasingly difficult toward the end of the first year of life. AtTAchient, supra note 13, at 324. The earlier the adoptive placement, therefore, the better the child's adjustment is likely to be, but shifts in caregivers, even during the early months of life, can produce undesirable symptoms. Mech, Adoption: A Policy Perspective, in 3 Review of ChiLd DEVELopMENT RESEARCH 467, 474 (1973).

26. Ainsworth, supra note 13, at 65-66; see Bowlby, Some Pathological Processes Set in Train by Early Mother-Child Separation, 99 J. Mental Scr. 265 (1953).

27. Wald, State Intervention on Behalf of "Neglected" Children: Standards for Removal of Children from Their Homes, Monitoring the Status of Children in Foster Care, and Termination of Parental Rights, 28 STaN. L. REv. 623, 671 n.192 (1976).

28. M. RuTrER, supra note 13 , at 77 .

29. Complete reversibility may occur if the deprivation ceases during the infancy period. See p. 1414 \& note 24 supra. But it is uncertain whether reversal can occur after two or three years of age. Clinical accounts suggest that reversal occurs only partially and with great difficulty after infancy, but systematic studies to support or refute that conclusion are lacking. See M. Rurrer, supra note 13 , at 77 .

30. See notes 21-22 supra. In a 1924 study of 95 children who had spent five years or more in an institution, nearly half were troublesome and delinquent when placed in a foster home. Child CARE, supra note 13, at 43. Such children may become adults who lack warmth in their contacts with other pcople. J. Goldstein, A. Freud \& A. Solnir, supra note 13 , at 33 . 
The harm resulting from separation from a parent is not restricted to infants. ${ }^{31}$ The type of harm that will result is in part a function of the age of the child at the time of separation. ${ }^{32}$ For a child between the ages of two and five years, separation from a parent affects skills developed through intimate interaction with a stable caregiver. ${ }^{33}$ The more recently the skill has been acquired, the more likely it is to be lost. Thus after separation from the parent, a child may suffer breakdowns in toilet training and lose verbal skills. ${ }^{34}$ Lack of continuity in parenting of a school-age child can cause academic difficulties and delinquent or criminal behavior. ${ }^{35}$

The severity and duration of these effects depend largely on the length of separation and on the child's age. The older the child, the longer the period of separation she can tolerate without ill effects..$^{30}$ Nevertheless, it appears that if a preadolescent child has no contact with a parent for longer than one year, reunion with the parent will not prevent serious emotional effects. ${ }^{37}$

The impact of a temporary separation can be lessened by measures that encourage the child to maintain the relationship with the parent. ${ }^{38}$ One such measure is regular visitation between the parent and child. ${ }^{30}$ Visits may better be able to mitigate harm to the child when the term of separation is short, but even when the separation is of longer duration, most authorities agree that the child's adjustment will be facilitated if the child frequently visits with her parent. ${ }^{40}$

31. H. Foster, A "BILL of Rights" FOR ChILdREN 24 (1974); Bodenheimer, Uniform Child Custody Jurisdiction Act, 22 VAND. L. Rev. 1207, 1208-09 (1969); Wald, supra note 13 , at 995.

32. J. GoLDsteIN, Medical Care for the Child at Risk: On State Supervention of Parental Autonomy, 86 YALE L.J. 645, 649 (1977). It has been noted that the gravest effects are seen between the ages of three months and two years, with a subsequent decrease in severity until the age of seven or eight. R. PatTon \& L. GARDNER, supra note 13, at 38.

33. J. Goldstein, A. Freud \& A. Solnit, supra note 13, at 33 .

34. Id. For examples of regression following separation, see generally A. Freud \& D. Burlingham, Infants Without Families 19, 21 (1944).

35. J. Goldstein, A. Frevd \& A. Solnit, supra note 13, at 33, 34. But Goldstein, Freud, and Solnit do not differentiate between the effects of separation per se and the effects of discontinuity in care. The adverse effects of separating children from their parents after infancy do not appear to be well established, but there is general agreement that the custodial arrangements that often result from the separation of parent and child during the childhood years are harmful to children. See pp. $1419-21$ notes 55.63 infra.

36. J. Goldstern, A. Freud \& A. Solnit, supra note 13, at $40-41$; R. Patton \& L. GARDNER, supra note 13 , at 38 .

37. J. Goldstein, A. Frevd \& A. Solnit, supra note 13, at 41.

38. A child will adjust to a temporary placement best if she is allowed to keep as many ties to the past as possible. Wald, supra note 13 , at 993 n.44.

39. A study of children in institutions showed that regular visiting by parents was sufficient to maintain relationships while the children were institutionalized. See Pringle \& Clifford, Conditions Associated with Emotional Maladjustment Among Children in Care, 14 Educ. Rev. 112 (1962).

40. Wald, supra note 13 , at 993 n.44. But the length of the separation and the amount of time between parental visits must be measured from the child's perspective, not from the adult's. The length of time required to disrupt an old attachment will depend 
The reunion of parent and child after separation may also be problematic.11 The child's ability to readjust to the relationship with the parent may depend in part on the parent's willingness and ability to respond to the child's needs.42 A parent newly released from prison may experience difficulties of her own in readjusting to life outside the prison and may not be in a strong position to meet the needs of her child. 43

Although in most cases of parental incarceration the child's welfare will best be served by maintaining the parent-child bond, in some situations the loss of the parent-child bond is inevitable. This may occur when the parent is subject to a long term of imprisonment, ${ }^{44}$ when the conditions of incarceration prevent contact between the parent and child, ${ }^{45}$ or when the parent has seriously harmed the child. ${ }^{46}$

on the different meanings that time has for children at different stages in their development, since children, unlike adults, are unable to anticipate the future and thus to manage delay. The older the child is, the longer is the period of separation she can tolerate without harm. J. GoldsteIn, A. Freud \& A. Solnit, supra note 13, at 40.

41. Difficulties in the mutual adaptation of parent and child following a separation have been noted in a child's return home after hospitalization, J. RoBerTson, Young ChILdREN IN Hospitals 11-54 (1958), and on the father's return after absence in military service, see Father Relations of War Born Children (L. Stolz ed. 1958).

42. Reunion with a parent after a separation represents another major change in a child's life and may produce anxiety and insecurity. J. BowLBY, ATTACHMENT AND Loss: Seraration 12-16 (1973) [hereinafter cited as Separation]. A parent who interprets this anxiety reaction as a reluctance of the child to reestablish the relationship may reject the child and thus further complicate the child's readjustment possibilities.

43. One parent newly released from prison expressed her feelings on being reunited with her children as follows:

Like any good mother, Rikers attempted to instill in me what they considered a good set of values. Because I had two children, Michael and Caja, I was told repeatedly that it was my utmost responsibility to return to society and become the perfect mother and that it should be a natural thing for me to assume. Unfortunately, they didn't prepare me for the traumatic reality of coming out of jail with children that have to be provided for immediately. They also were not dealing with the emotional trauma of my having to deal with the kids.

Glass, Coming Out of Jail ...A Woman's Trauma, Fortune News, Feb. 1977, at 6. Similarly, another exconvict has commented:

Women have special problems; they have their children. They have children who may have been taught while they were gone that "your mother is no good, she's not fit." When she returns this is the major problem that faces her, because her role as mother is the one in which she expects to be accepted.

Lawrence, An Ex-Offender Evaluates Correctional Programming for Women, I CRIM. Just. \&. Behavior 388, 390 (1974).

44. The average length of time served in prison varies greatly from state to state. In the study by R. GLICK \& V. Nero, supra note 1 , of the 1339 misdemeanants studied, $98.4 \%$ had been incarcerated for less than one year and only $.6 \%$ had been incarcerated for more than two years. Of the 3593 felons studied, $56.7 \%$ had been incarcerated for less than one year, $22.7 \%$ had been incarcerated for more than one year but less than two years, and $20.6 \%$ had been incarcerated for more than two years. Id. at 144. It also appears that, at least for violent crimes, women generally serve longer prison sentences than men. R. Dexing, supra note 1 , at 172 .

45. Contact may not be feasible if parents are known to be violent or are incarcerated in a maximum security facility.

46. But the parent's criminality is not itself evidence that the child has been harmed by the parent. Many states have recently rewritten child neglect statutes so that parental 
When the parent-child bond is certain to be lost, the child's interests may call for permanent termination of parental rights to allow the child to form a new bond with another adult. Except in these extreme cases, however, the child's psychological welfare will best be promoted by preserving her attachment to her parent to the greatest extent possible.

\section{The Failure of Existing State Practices to Protect the Best Interests of the Children of Prisoners}

Regardless of whether a child is left with relatives, placed in foster care, or institutionalized, under current practice the incarceration of a parent almost always involves the separation of parent and child. A child separated under these circumstances is not, however, guilty of any wrongdoing and thus she is entitled to be treated like any other child whose familial relationships are upset by state action. At present, the standard that guides state policy toward such a child is the protection of the child's best interests. ${ }^{47}$

The "best interests" standard has been widely adopted by courts ${ }^{48}$ and child welfare agencies. ${ }^{40}$ It has been recognized that this standard must be defined to include the psychological and emotional well-being of the child, since the psychological and emotional needs of a child whose parent is imprisoned are as important in assuring the child's normal development as are education or physical health and safety. ${ }^{50}$

rights may be terminated only if specific harm to the child is shown. See note 7 supra. This trend was initiated and has received support in the legal literature. See, e.g., Wald, supra note 27, at 642; Wald, supra note 13, at 1002-03.

47. Most states direct the courts to order the disposition of children in custody that promotes the child's best interests. See Wald, supra note 27, at 649; Comment, supra note 3 , at 129-30. Courts usually state that the basis on which they much make custody decisions is the best interests and welfare of the child, which include her physical, intellectual, moral, and spiritual well-being. Comment, Child Custody: Best Interests of Children us. Constitutional Rights of Parenls, 81 Drck. L. REv. 733, 733 (1977) (citing Commonwealth ex rel. Holschuh v. Holland-Moritz, $448 \mathrm{~Pa} .437,444,292$ A.2d 380, 383 (1972)). This standard has been said to apply in proceedings in which a child has been determined to be dependent or neglected. Johnson v. People ex rel. W_ J_, 170 Colo. 137, 142, 459 P.2d 579, 581-82 (1969).

48. But the concept of a child's "best interests" is not well defined and may be cited to justify many results. Foster, supra note 23 , at $1-2$. Courts use this standard because most statutes concerned with the custody of children use the "best interests" standard. Wald, supra note 27, at 631; see, e.g., CaL. CIv. Code $\$ 4600$ (a) (West Supp. 1978); Colo. REv. STaT. \$19-3-109(1) (1973).

49. When a child is removed from her home following a neglect hearing, the court does not decide specific placement of the child. Instead, the child is committed by the court to the care of a child-care agency or welfare department for placement. Wald, supra note 27 , at 631 .

50. Note, Alternatives to "Parental Right" in Child Custody Disputes Involving Third Parties, 73 YALE L.J. 151, 157 (1963). But it has been noted that most judges do not have, and are not given, psychological insights that would aid decisions about the child's best interests. Foster, supra note 23, at 2. 
It is clear, however, that separation from a parent jeopardizes the psychological and emotional development of a child; ${ }^{j 1}$ any state practice, therefore, that invariably separates a child from her parent when the parent is incarcerated and that does not provide for maintenance of the parent-child relationship during the period of separation undermines the state goal of protecting the best interests of the child..$^{\mathbf{2}}$

The failure of states to protect the child's best interests may be especially egregious when the separation of parent and child results in the taking of the child into state custody. In such cases, a child may not only be harmed by separation from her parent ${ }^{53}$ but also may suffer additional harm as a result of the conditions of care provided by the state.

When the separation of parent and child is to be only temporary, a child taken into state custody is placed either in an institution or in foster care. ${ }^{\$ *}$ Yet neither of these placements can provide an adequate substitute for the lost parent. A child in state custody is likely to be placed in an institution only when no other placement can be found, ${ }^{55}$ since it is now well recognized that institutionalization can be extremely detrimental to a child's emotional development. Injury results in large part because most institutions cannot provide the continuous and individualized care by a single caregiver that a child needs. ${ }^{56}$ As a result, institutionalization often leaves a child impaired in her ability to receive and return affection, to control her impulses, and to use her mind. ${ }^{57}$

In recognition of the shortcomings of institutionalization, child-care

51. See pp. 1413-17 supra.

52. Id.

53. Current practices of most states make no allowance for maintaining the parentchild bond when the parent is incarcerated. Comment, supra note 3 , at 129,138 . For the few states that do have statutes providing for the maintenance of an infant-parent bond during a mother's incarceration, see note 3 supra.

54. Children taken into state custody following the incarceration of a parent are differentiated from those left in the care of relatives. Children left with relatives suffer the adverse effects of the separation itself, see pp. 1414-16 supra, but another family member may be able to form a stable relationship with the child and thus mitigate the damage after the separation has occurred. Additionally, a small number (approximately one percent) of children in state care are placed in group homes. Mnookin, supra note 9, at 610 . Since the number of children in these group homes is so small, they are not discussed separately in this Note.

55. Mnookin, supra note 9 , at 610 .

56. See generally A. Freud \& D. Burlingham, supra note 34; Spitz, Hospitalism: An Inquiry into the Genesis of Psychiatric Conditions in Early Childhood, in The CompetenT INFANT 775, 775-88 (1973). M. RuTrER, supra note 13, at 69 , notes that less behavioral disturbance was found in institutionalized children who had been cared for by the same housemother for at least two years than in institutionalized children who had been cared for by many housemothers.

57. Paulsen, Juvenile Courts, Family Courts, and the Poor Man, 54 CALIF. L. REv. 694, 712 (1966). 
agencies usually attempt to place a child who is temporarily separated from her natural parent in a foster home. Yet foster care is also unlikely to provide the needed parental figure and the continuity of care that children require. Although foster care is intended to replicate the conditions of normal family life, this ideal is seldom realized in practice. First, a child newly separated from an accustomed caregiver is likely to be in great emotional distress. ${ }^{58}$ Foster parents capable of dealing effectively with a child who has emotional or behavioral problems are often difficult to find and, as a result, many foster children experience difficulties in establishing relationships with their foster parents. ${ }^{\text {*0 }}$ Second, because foster parents know that a child has been placed with them only temporarily, they may be unwilling to invest in an emotional relationship with the child in their care. ${ }^{60}$ Indeed, foster parents are often warned not to become too attached to the child so that their eventual separation will not be too painful for the child, and child welfare agencies often remove a child from a foster home if it is found that a foster parent has become too attached to the child. ${ }^{01}$ As a result of these difficulties, children in foster care are often relocated several times. Each such relocation further disrupts the continuity and stability needed for the child's optimal emotional development and deprives the child of a needed parent figure. ${ }^{62}$

Even a child in foster care who is not moved from one home to another may suffer psychological harm as a result of conflicting loyal-

58. See pp. 1414, 1416 supra.

59. The shortage of foster parents qualified to raise children who are under emotional stress or exhibiting behavioral problems has been noted by Paulsen, supra note 57, at 711 and by Wald, supra note 13 , at 994 .

60. Wald, supra note 27 , at 671 n.196.

61. See J. Goldstein \& J. Katz, The Family and the Law 1027, 1028-29 (1965) (quoting trial transcript that presents views of Child Care Association):

[Clara Miller, an officer of the Child Care Association] testified that the objection of the agency at this point is that Mr. and Mrs. Sanders [foster parents] have become too emotionally involved with the child and that it would be better for the child, who ultimately, she says, will be with the natural mother ... to be placed in a neutral home, a home where she would be liked, but not loved to the degree that the Sanderses love her .....

Often the difficulty is accentuated when parents are in prison, because unlike the children of neglecting or abusing parents, most of these children can expect to be reunited with their parents after their parents are released from prison. But usually neither the child nor the foster parent knows when the parent will be released from prison. Thus they are kept in a state of emotional limbo, and "no child can grow emotionally while in limbo.... He cannot invest except in a minimal way ... if tomorrow the relationship may be severed." Bryce \& Ehlert, 144 Foster Children, 50 Child Welfare 499, 503 (1971).

62. Mnookin, supra note 9, at 622-26; Wald, supra note 13, at 994 (citing CaL. Leg. Joint Leg. Audit Comm. Report on the State's Role in Foster Care in California 6.8 (No. 148.2, 1974)). 
ties. ${ }^{03}$ The relationship between a natural parent and a child in foster care often has not legally been terminated. During the parent's incarceration, however, the authority to make decisions about the child's care is divided between the foster parents and welfare personnel, ${ }^{6.4}$ with the latter maintaining control over significant aspects of the child's life. ${ }^{35}$ Although the effects of such ambiguous relationships with authority figures are difficult to measure, a child's emotional security and personal identity may be shaken by the conflicting expectations and loyalties developed through stays in foster homes. ${ }^{66}$ Lack of the solid identity that most children acquire in their relationships with their parents may cause foster children the most harm. ${ }^{67}$

Hence institutionalization, foster care, and placement with relatives all threaten harm to children because of the effects on children of separation from a parent. ${ }^{68}$ Institutionalization and foster care may create additional harm because of their failure to provide the child with a new stable parental figure. ${ }^{69}$ A child who is separated from her parent as a result of the parent's imprisonment occupies a unique position. Most often a child who is separated from her parent by state action is separated because of circumstances that indicate a breakdown in the normal parent-child relationship. ${ }^{70}$ But there is no reason to assume that this is so when a child is separated from a parent because

63. See J. Goldstein, A. Freud \& A. Solnit, supra note 13, at 25 ("[A foster child will] ... feel the impermanency and insecurity of the arrangement ... . He will feel himself in the care of parents who are by no means 'omnipotent' but have no more than partial protective power and control of his fate.") One study found that children placed in foster homes experience identity problems and conflicts of loyalty and may suffer from anxiety generated by uncertainty about their future. E. Weinstein, THE SELF-IMAGE of THE Foster ChILD 22-23 (1960).

64. Once a child has been placed in a foster home by a state agency, the agency sets limits and directions on how the foster parents are to behave toward the child. The shared control and responsibility for the child is set forth clearly in the instruction pamphlets issued to foster parents. See Smith v. Organization of Foster Families, 431 U.S. 816, 827 n.18 (1977).

65. Agencies frequently prohibit corporal punishment, require that children over a certain age be given an allowance, and forbid changes in the child's sleeping arrangements and vacations out of state without agency approval. Id. at 827 n.18. Most important, the agency retains the right to determine when the child is to be removed from the foster home, either for transfer to a new foster home or for return to the natural parents. Smith v. Organization of Foster Families, 431 U.S. 816, 827 (1977); J. GoldsteIN \& J. KATz, supra note 61 , at 1022 . In recognition of the contractual nature of the relationship, it was held in the Smith case that foster parents are not entitled even to notice and a hearing before removal of a foster child. 431 U.S. at 816 .

66. E. WeInstein, supra note 63 , at 47-57,66-70.

67. See generally ATtichneNT, supra note 13.

68. See pp. 1413-16 supra.

69. Sec pp. 1419-21 supra.

70. Most children who are placed in state custody are placed there because of "family problems," mental illness of the mother, or parental abuse, neglect, or abandonment. See Mnookin, supra note 9, at 607 (citing authorities). 
of parental incarceration. In such cases, it can ordinarily be assumed that there exists a parent-child bond of considerable importance for the child. ${ }^{i 1}$ Moreover, many parents in prison are concerned about their children and are anxious to maintain the parental relationship. ${ }^{72}$

These facts point to a plain conclusion. Much of the distress currently suffered by a child as a result of separation could be averted by allowing the child to maintain a viable relationship with her parent during incarceration. Although achieving this result would require substantial changes in existing institutional arrangements, these changes are necessary if states are to fulfill their announced policy of protecting the child's best interests.

\section{Proposals for the Care and Custody of the Children of Incarcerated Parents}

This section proposes reforms that take into account current knowledge concerning both the detrimental effects on children of separation from parents and the importance of continuity of care during childhood. ${ }^{73}$ The reforms are designed to ensure that children are not separated from parents during the critical infancy period and that parent-child relationships are maintained when the infancy period is past. Specifically, it is proposed that parents who are the sole caregivers of their infants be allowed to keep infants up to two years of age with them in the prison facility and that institutional changes be made to

71. It seems clear that most children are strongly attached to their caretakers. Wald, supra note $2 \overline{7}$, at $644-45$. It is also true that children often form strong attachments to parents who may not appear to outsiders to be "fit" parents, and may even form attachments to parents who cause them distress. ChILd CARE, supra note 13, at 78; M. RUTTER, supra note 13 , at 19.

72. A typical comment from a woman going to prison was reported in K. BURKHART, WOMEN IN PRISON 48 (1973): " "All I could think about was my kids. It was like they was slipping out of my hands-falling away and I couldn't hold on to them or keep them safe. It was like everything I knew in the world was suddenly gone." Many convicts report that separation from their children was the worst part of being in jail. Trecker, supra note 2 , at 88 .

73. For an argument that incarceration of the parent should not be the basis for termination of parental custody, sec Comment, supra note 3, at 129-37. This Comment advances proposals broadly similar to those presented here, including allowing infants to remain with mothers in prison, providing temporary furloughs for mothers to spend time with their children, and encouraging visiting between children and their mothers in prison. Id. at 137-44. In contrast, this Note argues that even temporary separation of children from their parents can seriously retard the child's emotional development. In light of this emphasis on the child's need for continuity of care, this Note suggests that states should take additional steps to maintain the parent-child relationship. These additional steps include the establishment of residential communities for parents and their children that would allow parents and children to remain together beyond the infancy years, use of the states' control over conditions of foster care to protect the bond between children and their biological parents, and the provision of services to facilitate the reunion or readjustment of parents and children after the parent has been released from prison. 
maximize contact between parents and children beyond the age of two years. These changes include providing residential communities where offenders can live with their children, and, where co-residence is impractical, facilitating interaction between parents and children by encouraging visitation and by providing furloughs to parents who wish to spend time with their families. It is suggested also that parental rights be legally terminated only in those extreme cases where the emotional bond between parent and child cannot be maintained, either because of the parent's past behavior or because of insurmountable constraints created by the sentence imposed on the parent.

\section{A. Protecting the Parent-Child Relationship}

In most cases, the best means of minimizing the distress caused to a child by a parent's confinement would be to permit a parent and child to remain together. This could be accomplished most effectively by the establishment of residential penal communities in which an offender could live with her child. ${ }^{7+}$ Such arrangements would be most suitable for a parent considered by correctional authorities not to require high security confinement. ${ }^{75}$

74. One objection that might be raised to housing children with offenders is that children are likely to imitate the behavior they see around them and thus become criminals themselves. This does not, however, seem to be a realistic concern. Parents are unlikely to be engaging in visible criminal behavior while they are residents of a supervised community. Morcover, studies showing that children model their behavior upon what they see have been largely concerned with the children's immediate response to an aggressive model, and the resultant childen's behavior has mostly consisted of assertive or mildly aggressive behavior within the range of normality. Bandura, Social-Learning Theory of Identificatory Processes, in HANDBOOK of SOcIALIzation THEORY AND RESEARCH 213 (D. Goslin ed. 1969).

A residential facility for adult offenders and their children currently exists in Norristown, Pennsylvania, and is known as Cluster II. The women serving sentences there live in semi-detached houses in a Philadelphia suburb. A woman may be committed to Cluster House as an alternative to serving a term in prison or else to serve out the last three to six months of her sentence. Residents are required to tend to their children, clean the rooms they share with them, do assigned chores, undergo mandatory in-house therapy once a week and either to find employment or to enroll in a job training program. Cluster House is funded through the Governor's Justice Commission by a grant from the Law Enforcement Assistance Administration and by the $\$ 60$ per month payments required of every employed resident. So far, Cluster II has not had any problems with escape attempts, vandalism, or child abuse. Brattleboro Reformer, Oct. 7, 1977, at 13, cols. 4-7 (on file with Yale Law Journal).

There are other prison facilities that now do not house children but that could easily be adapted to do so. For example, the Detroit House of Corrections now consists of a group of small buildings that resemble multifamily homes. Each cottage is designed to be self-sufficient and contains individual rooms, as well as kitchen facilities. R. GLICK \& V. NeTo, supra note 1 , at 20. Facilities with similar designs could easily be adapted to house children, and legislatures should be encouraged to consider the construction of such facilities when money is being allocated for the construction of new prisons.

75. The President's Commission on Law Enforcement and Administration of Justice urged correctional authorities to develop more extensive community programs provid- 
Even when the parent is incarcerated in a conventional prison facility, it may sometimes be advisable to allow the child to remain with the parent. The age of the child will usually be the critical factor. When a parent who is the sole caregiver of a child under the age of two years is imprisoned, nursery facilities should be provided to make it possible for the child to remain in prison with the parent. During this critical early period, it is crucial that the bond between parent and child be protected; ${ }^{76}$ separations of even short duration may be intolerable for the infant. ${ }^{77}$ Although this suggestion may seem startling, laws have already been passed by three states allowing infants up to the age of eighteen months to remain with parents in prison, ${ }^{78}$ and infant nurseries have already been set up in several women's prisons. ${ }^{79}$ A child

ing special, intensive treatment as an alternative to institutionalization for adult offenders. President's Commission on Law Enforcement and Administration of Justice, The Challenge of Crime in a Free Socicty 170-74 (1967). Nevertheless, these suggestions have largely been ignored by federal and state governments, which continue to spend large sums of money to build new prisons. K. BuRKHART, supra note 72, at 428-29.

76. See pp. 1411-15 supra.

77. See note 24 supra.

78. See note 3 supra. These provisions, however, apply to women prisoners only. No state yet permits a child to remain in prison with her father, even if the father is the sole caretaker of the child at the time of incarceration.

79. Bedford Hills Correctional Facility in Bedford Hills, New York, maintains a nursery within its medical building for the newborn babies of inmates. Mothers can live in a private room with their infants for up to 18 months after delivery. Junior League of the City of New York, supra note 1, at 9; Trecker, supra note 2, at 89. But even here the women are encouraged to make other arrangements for their children as soon as possible. Id. The State Correctional Institution in Muncy, Pennsylvania, allows infants to remain in the prison hospital until an alternative placement is arranged, usually within a month. Mothers live in their own cottages, but spend half days in the hospital with their infants. Junior League of the City of New York, supra note 1, at 9.

In its interview's of prison officials, the Junior League found mixed support for allowing children to live on prison grounds. For statements opposing such a plan, sec id. at 12-13 (citing administrative problems, inappropriateness of prison environment for children, and suggesting that many mothers would not be "sincerely interested" in giving proper care to their children). But cf. id. at 12 (one official suggesting that "mother-child contact is extremely important"). Some opposition, however, may result from ignorance. Both parents and correction officials may be unaware of the harm that is caused to children by separation from their parents during infancy. In addition, until legislatures appropriate money to provide safe and sanitary facilities in which infants can live, the thought of raising children on prison grounds may be unappealing to many parents.

Yet there is some evidence that raising a child with a parental figure in even a very poor quality institution may not be harmful to the child. One study on the effects of institutionalization on infants under the age of one year found that infants raised in the nursery of a penal institution for delinquent girls were "well-developed and normal." Spitz, supra note 56, at 778. In explaining his results, Spitz emphasized the amount of attention and care that was lavished on the children by the delinquent mothers. In the particular institution studied, 69 infants were housed in a nursery supervised by a head nurse and her three associates. The staff's duties consisted mainly of teaching the mothers about child-care and of supervising the mothers. The children were fed, nursed, and cared for by their own mothers. Spitz noted the contrast between this group and other children raised in a regular orphanage who had "spectacularly deteriorated." Id. 
above the age of two or three, however, should not remain in prison with the parent. ${ }^{s 0}$ By this time, the parent-child bond is well established, and the child's physical and emotional needs require freedom of movement and contact with other children that may not be available in the prison setting: ${ }^{81}$

When the parent is imprisoned and the child is too old to remain in a prison nursery facility, the parent should be encouraged to make independent arrangements for the care of the child during the period of imprisonment. Even when a parent succeeds in making such arrangements, however, the best interests of the child may require that the child welfare department retain some continuing responsibility. The agency should make certain that the parent's arrangement satisfies the standards set in neglect or unfitness statutes for regulating the care of children, and the agency should maintain sufficient contact with the child throughout the period of the parent's imprisonment to ensure that these standards are consistently met.

When a parent and child must be separated, frequent contact between parent and child will be instrumental in preserving the parentchild bond and in reducing the child's emotional distress. ${ }^{82}$ Although states cannot require a child to visit a parent in prison, steps should be taken to facilitate visitation. For example, institutional rules that severely limit the duration, frequency, and circumstances of visitation between a parent and child should be modified. ${ }^{83}$ A child should be permitted to visit her parent for several hours at a time at least once a week, and comfortable surroundings that permit normal interaction and physical contact between parent and child should be provided. ${ }^{8 t}$

80. The age at which the child is separated, however, must be kept flexible. There are substantial differences among infants in the development of relationships, and chronological age itself may not be a very sensitive index of the level of the child's relationship with her mother. Yarrow, supra note 23 , at 122.

81. Children Iearn how to interact with the environment by exploration. The tendency to explore usually begins around the age of 18 months and increases greatly over the next few years. Children whose exploratory behavior is overly restricted during these early years may grow up with strong inhibitions against trying anything new or challenging, including attempts to develop relationships with other people. J. KaGAN \& E. HavemanN, supra note 13 , at 538 .

82. See p. 1416 supra.

83. Many prisons currently bar visitors under the age of 16. Even where children are allowed, visiting rights are usually very limited. $R$. Deming, supra note 1 , at 158 . Mothers usually must see their children through glass and are not permitted to have physical contact with them. Singer, supra note 1, at 302 (1973). In addition, agency workers often discourage visitation by children in foster care. Trecker, supra note 2, at 90-91; Wald, supra note 13, at 995 n.58.

84. Maryland, Nebraska, Oregon, and Alabama have developed successful liberalized visitation plans. See Junior League of the City of New York, supra note I, at 10-11. For example, at the Maryland Correctional Institution for Women, there is a weekend pro- 
Child-care agencies should assist relatives or other temporary caregivers to make arrangements for transportation of the child to and from the prison. ${ }^{85}$

In many cases, a parent should be permitted to spend time with her child outside the prison. Many states already allow convicted persons to leave prison for limited periods of time to further their education or to maintain jobs. ${ }^{86} \mathrm{~A}$ parent who qualifies for such part-time release programs should be permitted to spend equivalent amounts of time with her child away from the prison. She should also be given the option of combining a program of part-time parenting with part-time release for work or education to acquire skills that will later ease her readjustment to life outside the prison. Although such arrangements would require that another caregiver be available part-time, they would minimize the adverse effects of separation and allow the parent and child to maintain a relatively normal relationship during the parent's incarceration.

Realistically, of course, a parent will sometimes be unable to make suitable arrangements for the temporary care of her child during the period of incarceration. When the state takes such a child into custody, it should attempt to provide conditions of care that minimize the psychological damage to the child that may result from separation. Such a child should be placed in a foster home whenever possible and institutionalized only as a last resort.

State officials responsible for supervising children in foster care should ensure that a child of an incarcerated parent is placed in a home that is located as close as possible to the parent's prison facility ${ }^{87}$ and that foster parents take all reasonable steps to maintain the child's relationship with the incarcerated parent.

Foster care is arranged by contract between the state and the foster

gram every week that includes organized games, films, and leisure visitation. Id. at 10 . The Nebraska State Reformatory has a program called Mother Offspring Life Development (MOLD), which allows children under 16 to stay in the rooms with their mothers for up to a week. Id. at 10 .

85. Of the 16 prisons studied by R. GuIck \& V. Nero, supra note 1, at 12, 11 did not have public transportation coming within five miles of the prison.

86. Id. at 86, 183-84; see Comment, supra note 3 , at 140,141 .

87. Difficulties may be caused if prison authorities transfer prisoners to other facilities, thus requiring children to change foster homes in order to maintain contact with their parents. Courts have recognized that a prisoner's interest in being imprisoned close enough to home to allow family visits is of sufficient significance to justify a hearing prior to an out-of-state transfer. E.g., Capitan v. Cupp, 356 F. Supp. 302 (D. Ore. 1972). But cf. United States ex rel. Gereau v. Henderson, 526 F.2d 889 (5th Cir. 1976) (hearing not required prior to transfer of prisoners if transfer not for disciplinary reasons). It is sug. gested that a prisoner's interest in maintaining contact with her child should be grounds for requiring a hearing before that prisoner is transferred to another prison. 
parents. ${ }^{88}$ The state, therefore, can set conditions that foster parents must respect concerning the care of the foster child. ${ }^{59}$ Child welfare officials should exercise this power to require the foster parents to consult and reach agreement with the child's parent on important decisions concerning the child's welfare. ${ }^{00}$ Such consultation will reduce the tension experienced by a child caught between the conflicting expectations of her own parent and the foster parent. ${ }^{91}$ State officials should not interfere with decisions concerning the child's welfare except to the extent necessary to assist the foster parents and a natural parent to reach agreement. The foster parents should also be required to arrange for the child to visit her parent in prison regularly.

When a parent is released from prison, services should be provided by state agencies to facilitate the reunion of parent and child and to assist the parent in adjusting to life outside the prison, regardless of who has cared for the child during the parent's incarceration. ${ }^{92}$ These family reunification services should include, but not be limited to, emergency housing, employment counseling, housekeeping, and daycare services for limited periods of time until the parent finds employment, crisis intervention care, and family therapy. ${ }^{93}$ Only by providing such services can states maximize the likelihood that a former prisoner will be able to resume her role as parent and provider successfully after a period of incarceration.

88. E.g., Smith v. Organization of Foster Parents, 431 U.S. 816, 856 (19خר).

89. Id.

90. A program of cooperation between prisoners and foster parents has been instituted in the state of Washington. If an incarcerated mother wishes to take responsibility for her child, the mother has a series of meetings with the proposed foster parents before the child is placed in the foster home. At these meetings, the mother and the foster parents discuss how the child is to be raised. The foster parents must make a commitment to bring the child to visit once a week, and the mother is encouraged to take a furlough to see her child's new home. The foster mother is expected to visit the inmate, and if problems arise between them a meeting is arranged with the social workers and child welfare workers. Junior League of the City of New York, supra note 1, at 21-22. For a discussion of the problem of conflict between the foster mother and the natural mother, see id.

91. See pp. 1420-21 supra.

92. When a parent is incarcerated, her family ties are severed to some extent, regardless of whether or not she is able to maintain contact with her child. Yet prison officials and welfare workers do very little to repair those ties. Although many in-prison counseling programs have been instituted in recent years, with topics ranging from religion to relationships between the sexes, programs designed to help incarcerated adults reassume roles as parents are lacking. Trecker, supra note 2 , at 93 . In addition, foster care agencies usually focus attention on the child and the foster parents, spending little, if any, time with the natural parent. Mnookin, supra note 9, at 612 .

93. One example of a statute establishing such family reunification services for parents whose children have been placed in foster care is CAL. WELF. \& INST. CodE $\$ 16525$ (WVest Supp. 1977). 


\section{B. The Last Resort: Terminating the Parent-Child Relationship}

The proposed reforms should make it possible for an incarcerated parent to maintain her relationship with her child in most instances. In a limited number of cases, however, it may nonetheless be ill-advised to attempt to preserve the parent-child relationship. Such a case may arise when the parent is subject to an unusually long term in prison, when the conditions of the parent's sentence require maximum security and preclude visitation, or when the parent has caused serious harm to the child.

To minimize uncertainty over the child's placement, any decision to terminate parental rights permanently should be made shortly after the sentence of imprisonment is imposed on the parent. ${ }^{94}$ Initial responsibility for reviewing the child's case should be placed in the child welfare department..$^{95}$ If, in the opinion of this agency, the child's interests require permanent termination of parental rights, the agency should move for a hearing in the family court. At such a hearing, the burden should be on the state to prove by clear and convincing evidence either of two grounds for termination of parental rights. As one ground, the state could demonstrate that past behavior of the parent has been sufficiently harmful to the child to warrant an end to the parent-child relationship. In making this determination, the court should apply the standards applicable to proceedings under general child abuse or parental unfitness statutes. ${ }^{90}$ Alternatively, the state could attempt to establish that, apart from the nature of the relationship with her natural parent, the child's need for a permanent home is so urgent as to require immediate termination of parental rights and adoption of the child. This second ground for terminating parental rights would involve two distinct showings. First, the state would be required to establish that, due to the length of the parent's expected prison term and the age of the child, the parent would not be released soon enough to ensure that

94. Some time will be necessary for the child welfare department to investigate the situation and the options available for the child. However, the time between the sen: tencing of the parent and the decision whether to retain or terminate parental rights should be held to a minimum so that the child is not left unnecessarily in an uncertain position about her future.

95. The most efficient system of coordination between the courts and the welfare agency would probably require that the Department of Corrections file a form with the welfarc department containing information about an offender's parental status whenerer an offender is sentenced to a term in a correctional facility. A member of the child welfare department would then be assigned to each case. The responsibilities of this case worker would include contacting the parent to educate her about the potential adverse effects on children of separation from a primary caregiver and to determine her wishes concerning her child's placement.

96. Specific standards, of coursc, are preferable to vague ones. See p. 1410 supra. 
a normal parent-child relationship could be maintained. ${ }^{97}$ If the length of time to be served in prison is uncertain, the earliest possible date of release should be used as the basis for decision at the hearing, although the court should reserve the right to hold another hearing if the parent's sentence extends significantly beyond the projected date. Second, the state would be required to establish that a suitable alternative permanent placement for the child is available. ${ }^{98}$ Without such a placement, the child's need for continuity of care cannot possibly be met by termination of the relationship with the natural parent, and no termination proceeding should make a child an orphan who moves from one institution or foster home to another, without even nominal ties to a natural parent.

Termination of parental rights based solely on the length or conditions of the parent's prison sentence should occur only if an alternative permanent placement is available. Although termination on the grounds of parental misconduct should not require a showing that an alternative placement is available, vigorous efforts should nonetheless be made to find such a placement. In either case, a decision to terminate parental rights should be implemented immediately, and the adoption agency should act to facilitate adjustment of the child to the new family.

\section{Conclusion}

If termination of parental rights upon the incarceration of a parent is limited to a very narrow category of cases, and full consideration is given to current knowledge about child development, harm to a child caused by the incarceration of a parent can be minimized. Courts and legislators have too readily assumed that people who commit crimes are necessarily unfit parents, and have paid too little attention to the importance of a strong and permanent bond between parent and child for the emotional development of the child. Only when more concern is shown for the emotional ties between parent and child, and less concern given to the physical surroundings in which a child is raised, will the states truly be serving the best interests of children.

97. See p. 1416 supra.

98. The record of courts and social agencies in finding placements for neglected children is poor. See Wald, supra note 13, at 994 . The problem is exacerbated by the fact that the majority of prisoners in this country, and especially of women prisoners, are from minority groups; it is particularly difficult to find adoptive homes for these minority children. Ketcham \& Babcock, Statutory Standards for the Involuntary Termination of Parental Rights, 29 Rutgers L. Rev. 530, 543 (1976); Mech, supra note 25, at 469. 